\title{
Covid-19:
}

\section{A Stress Test for Trust?}

To tackle the Covid-19 pandemic, governments need citizens to trust messages on behaviour change, and to support more draconian steps like lockdowns. Yet, lack of trust in public authority and a prevalence of rumours are shaping people's responses to the virus, especially in fragile, conflict-affected places. Action for Empowerment and Accountability (A4EA) research among poor and marginalised households in such areas shows how distrust causes serious problems - and how approaches tailored to local contexts can mitigate these.

\section{Why who is trusted matters in contexts of uncertainty}

Since the start of the pandemic, uncertainty has coursed through public discourse about appropriate Covid-19 responses - be it herd immunity or 'test and trace'; masks or no masks - and now about the safety and effectiveness of vaccines approved rapidly by governments. Unsurprisingly, any official response prompts diverse interpretations and a varied reception from the public. Yet, across the world, experience unequivocally backs the need for a coordinated response, which requires everybody to change behaviour, in a collective and sustained way. Achieving this is particularly hard in places where most messages from state authorities are viewed sceptically.

Where governments have a history of using misinformation for political reasons, or to attract donor funding, or as a strategy for control, such scepticism is hardly surprising. Can the Covid-19 pandemic offer an opportunity to rebuild trust? Can it help to identify sources of authority who are trusted to provide credible information and to protect and 
deliver public goods to the poor and marginalised?

Serendipitously, our A4EA research to understand how people accessed 'governance' at local levels enabled us to explore these issues. Using our "governance diaries" methodology, we were already following poor and marginalised households in three countries with fragmented authority, conflict, uncertainty and legacies of repression. All three are fragile democracies, with parts engaged in conflict. ${ }^{2}$ The presence of the state is limited and contested by other non-state actors, especially in areas far from the capitals.

We found that poor and marginalised households rarely approach public authorities directly in these contexts. Instead they turn to local brokers and informal leaders at community, village, settlement or neighbourhood level - we call these people 'intermediaries' and included them in our research. ${ }^{3}$ Knowing the preferences and incentives of these intermediaries is part of understanding how issues are resolved. For example, women report needing to go through male intermediaries (they often are men) to solve their problems.

When the pandemic struck, we looked at how people and authorities have responded to Covid-19 in the three countries. Our key finding is that, at the margins, a lack of trust in public authority and a prevalence of rumours are shaping people's responses to the virus.

\section{Six observations from our research sites}

\section{Government information trickles down through public officials and the media}

First, the good news: in all our research sites, governments are reaching the population with information about Covid-19. Mostly this is through two channels - public officials and the media. Key sources of information for marginalised groups are local government functionaries - mainly public administration officials, but also others - and, in Country A, the police and the military. In the three countries, authorities send information to local leaders, including religious and traditional leaders who are expected to disseminate it. Armed groups also disseminate information about the pandemic through their local structures.

Local loudspeakers, radio and television are used for dissemination. Social media is widely used, and people are not just passive consumers. There is some awareness among intermediaries that these channels might spread misinformation. But most importantly, person-to-person communication dominates. As one person in Country C stated, 'Besides radio, the main way to have information is the interpersonal communication, conversations in passenger transport, in the market.'

\section{Trust in official information varies - and is sometimes very low}

Second, some more good news: in at least one of our research countries, the information coming from government is basically sound, and viewed as somewhat credible. In Country A, a country in transition from military rule, people trusted information from both government and armed groups not aligned to the government. When Covid-19 cases increased significantly, people started following the regulations more assiduously.

In Country B, messages are mixed. The population has long been fed conspiracies, so there are alternative theories about the information being received. Its credibility depends upon whether local intermediaries reinforce the messages. Even in Country $A$, where official information is trusted, it sits beside rumours and competing narratives about Covid-19.

Intermediaries in Country $\mathrm{C}$ do not trust the information coming from government. They call it an 'invention of the authorities' as they see no evidence about widespread

${ }^{2}$ Countries were anonymised for security reasons.

${ }^{3}$ For more information on this ongoing project, see the Governance at the Margins page on the IDS website. 
prevalence or severity. One intermediary we spoke to said, 'the government does not show infected people, and this makes people conclude that it is a play disease.'

\section{Rumours and informal sources of information prevail}

Our first phase of 'governance diaries' research showed that in settings of fragility and conflict, and for communities living on the margins (of economic power and political influence), informal sources of information trump formal ones. Unsubstantiated rumours rule. Covid-19 is no exception: Countries B and $\mathrm{C}$ are rife with rumours about the disease. These include conspiracy theories about its origins and authenticity as well as about people's own probability of getting infected and suffering.

Several tropes appear to co-exist about the origins of Covid-19 in both countries. In many sites, people do not believe that the disease is real: 'I know it came from China, but I have doubts because China is very developed and has the capacity to develop medicines.' Some explained it as 'the government's drama to get aid from the West.' Others claim it is 'a conspiracy against our religion' - prompting more people to attend churches/temples/mosques for prayers (and consequently contravene social distancing rules).

In Country A, the fear is focused more on outsiders and foreigners: 'The disease is more likely to be spread from people who come back from abroad. As you know, rural folks are really afraid of such matters.'

\section{4. 'It's just like flu': beliefs that the virus isn't a big risk}

Intermediaries and people believe that they are unlikely to get the disease, and this is reinforced by repetition through informal channels. One key reason mentioned is that it is a disease of outsiders/rich/white people. For example, one person in Country B said: 'It's a foreign virus, how can we get it? We have not been out of the village.'

Another added, 'It's a virus of the rich

\section{Tensions between believing official government information and rumours reflect local dilemmas and lead people to behave in ways that undermine efforts to contain Covid-19.}

people, we are poor.' These sentiments are echoed in Country C: I'm not going to catch this disease, it's the rich man's thing. We already had serious diseases and we did not die.'

This was a recurring theme - of being resistant because they had experienced ill health and malnutrition. In Country B, some think that the virus will not affect poor people because the government has already exposed them to more lethal germs by housing them near dirty fords where drainage water flows.

According to one intermediary, 'our immune system is very strong, this is just a flu-type virus.' Others noted that they would not be affected because they are used to consuming unhygienic goods - they mentioned eating red pepper that is adulterated with crushed bricks, and milk powder mixed with washing powder.

In other words, if the government really cared and was to be trusted, it would not have left people in such dire health conditions.

\section{Official public health rules are not the main drivers of behaviour}

Tensions between believing official government information and rumours reflect local dilemmas and lead people to behave in ways that undermine efforts to contain Covid-19.

In Country B, intermediaries report that people are not following official requirements. For example, they gather in groups but hide when the police or other officials visit. Busy markets quickly empty when inspection teams 
arrive and go back to normal when they leave. Government efforts to increase testing face challenges because people avoid tests for fear of being diagnosed as positive and being forced to quarantine.

In Country C, people are not following lockdown regulations, because they need to earn a living to survive. They know the risks, but ignore preventive measures, like wearing masks, as they cannot afford masks when food is scarce.

Country A is slightly unusual, as for the most part, people are reported to be following the rules, especially as cases have increased. However, the rules have been created locally - 'every village has its own set of rules'. Village rules can be stricter than government guidelines and often it is up to intermediaries to negotiate and enforce them. Villages have also created their own security teams - posting guards at village entrances to prevent people coming in or going out and restricting traffic to essential only. These strategies reflect the belief in Country A that the threat is from outsiders, especially crossborder migrants who are quarantined upon return to their villages.

\section{Heavy-handed responses from the police and security forces}

Police action (or other security-related authorities) in response to transgressions has been, for the most part, heavy-handed and increases distrust of government. In Country $\mathrm{C}$, police are using intimidation and threats, accusing people of not following social distancing rules or of breaking the movement

\section{“}

\section{Our research on}

intermediaries suggests that they are the primary

interlocutors between people and higher forms of authority,

making them key players in

mediating trust. ban: 'the police are threatening people, they are extorting people especially the taxi drivers.'

In some locations, the local mafia have announced that they will kill anyone who has Covid-19, so people are afraid to seek health care even if they have other ailments, leaving them at risk of falling seriously ill. In Country B, citizen-state relations have long been shaped by legacies of security and policing. As one intermediary noted, 'the only thing we usually get for free are police beatings.' In Country A, a history of repression and fear of armed state and non-state actors have meant that people are afraid to break the rules lest they are beaten, fined or even imprisoned.

\section{Back to trust: how is it shaped?}

Given how government responses and messaging get subverted due to a lack of trust on the ground, what can we say about who holds the trust of the people?

Our research on intermediaries suggests that they are the primary interlocutors between people and higher forms of authority, making them key players in mediating trust. Overall, they seem to be using Covid-19 to gain or retain power in this role. They seem to operate in two ways: on the one hand, raising voices from below to get authorities' attention (and competing with other intermediaries to do so), and organising local-level collection and distribution of food and social protection money. On the other hand, they are the main channels for authorities to access communities, as they assemble beneficiary lists and pass on government messages.

Our early findings indicate that for the most part, people do not have a real choice of which intermediaries to use. However, intermediaries do have a choice of which authorities - state or non-state - they take people's problems to for resolution. Their choice depends on a range of factors, including their networks, nature of the problems, and potential for resolution. Yet, by these very choices, they have the potential to strengthen the reputation, legitimacy and trust in some authorities versus others. 
In Country A, intermediaries are struggling to navigate this space. As the situation gets more desperate, tensions are rising and they get 'stuck' between regulations set by government or non-state armed groups and community needs. This is severely degrading the relationship between communities and intermediaries.

In a situation such as Covid-19, when governments desperately need the trust of the people, understanding this local-level dynamic seems a vital factor.

\section{Some implications}

Given the distrust of state authority, persistent rumours and behaviours that undermine efforts to contain the virus, what can governments, donors and other external actors do? We suggest three key steps that can help transform the situation.

\section{Adapt social protection programmes to fit local realities}

First, most countries affected by the virus have implemented social protection programmes for the poorest and most marginalised. For these programmes to work, we argue that it is key to understand local contexts and the role of intermediaries in connecting poor populations to state systems. This means recognising the microcontext and the nuanced relationships between the actors on the ground. Working with intermediaries, whether formal or informal, who know the local populations and have an interest in advancing the public good seems critical. These grass-roots intermediaries are best placed to navigate any shifting political terrain.

Yet governments often implement programmes with no understanding of the micro-context. In Country A, some households got repeated provisions and others got nothing, due to poor selection criteria. Intermediaries there wish that the government would stop giving misguided support. Even households feel that the government does not understand their situation. In Country B, some households responded to mistargeting by redistributing among themselves, but governments cannot rely on such goodwill. In sum, social protection has the potential to ensure that people adhere to the rules without needing to choose between starvation and illness, and also to strengthen trust in government - but only with a nuanced understanding of the local context.

\section{Understand how messages get through to people}

Second, how information is mediated, and what incentives and reach the mediators have must be understood. There are perverse dynamics in the role that some intermediaries may be playing in hyping up the risks, resulting in people not getting tested, or avoiding health care due to fears about catching Covid-19, being thought to have it, or testing positive and subsequently being ostracised. Countering these negative perceptions will be key to catching cases early, as well as preventing a larger health crisis through neglect of other issues. The intermediaries who emerge as crucial in governance issues are predominantly men. In some contexts, there may be differences between how men and women, or people of different ethnic identities or political affiliations, get their information, and who they trust. This warrants exploration. A greater understanding of intermediaries and their incentives is needed to find the right people to work with and to frame the right messages.

\section{Frontline administration to build trust with citizens}

Third, nuanced understandings of the local context can only happen by re-orienting the frontline administration. In many countries with a colonial or military authoritarian legacy, the local administration treats poor and marginalised people as second-class citizens and rarely attempts to build trusted relationships with them. The Covid-19 crisis highlights the need for administrations to change their approach and to actively build trust with these populations - even if it will take years to change cultures and mindsets. 


\section{Final reflection: a response that is nuanced and tailored to the local context will go a long way towards strengthening trust}

We find that at the margins people make rational calculations, weighing the risk of getting Covid-19 against the risk of not meeting other critical needs.

Some people we talk to do not believe Covid-19 is real. They absorb messages best through direct experience, through the stories of people who have been affected by Covid-19, and for the most part, these stories have not reached them. Visual cues and informal channels can reinforce messages. In Country B, where cases have been relatively low, people in remote areas get rumours about rumours: second- or third-hand information, with the pandemic seeming quite distant from their everyday lives. In Country C, the government only recently authorised local media to film and diffuse images of Covid-19 patients being

Institute of Development Studies, Library Road, Brighton BN1 9RE, United Kingdom +44 (0)1273 606261 ids.ac.uk

IDS is a charitable company limited by guarantee and registered in England. Charity Registration Number 306371. Charitable Company Number 877338.

A4EA: W www.ids.ac.uk/A4EA Y'twitter.com/A4EA_Research

\section{Further reading}

Chaimite, E. and Posse, L. (2020) Why Are Women Still Excluded from Public Decision-Making in Mozambique?, IDS Opinion, 26 March

Governance at the Margins Research Team (2020) Mediating Between the State and its Poor and Marginalised During Covid-19, IDS Opinion, 17 June

Posse, L. and Chaimite, E. (2020) Perceptions of Covid-19 in Mozambique and the Influence of 'Intermediaries", IDS Opinion, 12 November

ISBN: 978-1-78118-768-5 DOI: 10.19088/A4EA.2021.001 treated. The reaction of colleagues of our researchers is illustrative - 'wow, it is real after all!' In places at high risk, authorities must increase awareness that Covid-19 is real, as people only seem to change their behaviour once the devastation of the illness becomes obvious.

On the other hand, the effect of restrictions on livelihoods is immediate and brutal. In Country A, the government closed international and domestic borders around a specific location at short notice, causing worries, chiefly economic, about work and income.

The stress of accessing basic needs appears to be as bad, if not worse, as concern about the virus. Given these observations, governments should adjust restrictions to local risk levels. Restrictions for precaution's sake do not make sense in circumstances where people don't have reserves to draw upon. A response that is nuanced and tailored to the local context will go a long way towards strengthening trust.

This Briefing was written by the Governance at the Margins Research Team and edited by Emilie Wilson. It was produced as part of the Action for Empowerment and Accountability (A4EA) programme.

A4EA is an international research programme which explores how social and political action can contribute to empowerment and accountability in fragile, conflict, and violent settings, with a particular focus on Egypt, Mozambique, Myanmar, Nigeria and Pakistan. It is funded with UK Aid from the Foreign, Commonwealth \& Development Office (FCDO).

The opinions expressed are those of the authors and do not necessarily reflect the views or policies of IDS or the UK government. (c) Institute of Development Studies 2021.

(7) This is an Open Access briefing distributed under the terms of the Creative Commons Attribution 4.0 International licence (CC BY), which permits unrestricted use, distribution, and reproduction in any medium, provided the original authors and source are credited and any modifications or adaptations are indicated.

\begin{tabular}{|c|c|c|}
\hline $\begin{array}{l}A 4 E A \\
\text { Action for empowerment and } \\
\text { accountability research programme }\end{array}$ & $\begin{array}{l}\text { institute of } \\
\text { development } \\
\text { studies }\end{array}$ & UKaid \\
\hline
\end{tabular}

